\title{
Implementation of Microservice Technology on Mobile Learning Development
}

\author{
Maksy Sendiang \\ Information Technology Dept \\ Manado State Polytechnic \\ North Sulawesi - Indonesia
}

\author{
Jerry H. Purnama \\ Mechanical Engineering Dept \\ Manado State Polytechnic \\ North Sulawesi - Indonesia
}

\begin{abstract}
Software development using microservice has many advantages over conventional technology. The short number of comprehension and applied examples of microservice technology have caused the software developed using this technology is confined. This research aims to apply microservice technology in the development of mobile learning (MLearning). Implementation of microservice will break the application into stand-alone entities and isolated with others. Thus failure in an entity will not effect the application as a whole system. This research using a mixture of quantitative and qualitative methods in collecting and analyzing data. The data obtained is modeled with an objectoriented approach by used Unified Modelling Language tool (UML). RUP method as one of software development method that gives focus to software architecture is used to develop the MLearning. By this research expected a MLearning is produced using microservice technology. It is expected this MLearning will improve the quality of education in Manado State Vocational High School. The conclusion of this research is that the development of MLearning with microservice technology will form a robust application that gives a positive impact on teaching and learning process at Manado State Vocational High School.
\end{abstract}

\section{General Terms}

Web development, Cloud computing

\section{Keywords}

Microservice,mLearning,entity,UML,RUP

\section{INTRODUCTION}

In the era of digital technology, the use of mobile devices become a necessity for both individuals and organizations to improve their performance. Mobile devices have become practical tool in accessing information and communication, so they are used in various fields the such as education, health, social and others. The rapid development of mobile devices is supported by the progress of innovation in both hardware and software. In the field of software, the proliferation of mobile applications such as eLearning, eGovernment, games have added software functionality and have an impact on the market demand for mobile devices that continues to increase over time.

According to Cavus \& Ibrahim [2009], Mobile learning enables multimedia communication by deploying text, voice, video and graphics. It can be achieved by collaboration between mobile devices such as cell phones, laptops, PCs, PC tablets, PDS and other handheld device with wireless internet network. MLearning allows student to exchange messages, sounds, pictures and other rich correspondence among themselves utilizing internet. Sanchez [2015] says MLearning is any kind of learning that happens when the learner is not controlled by time and location. Mobile learning happens when the learner applies mobile technologies to absorp the learning materials. By using mobile learning students with various backgrounds even those with disabilities can take advantage of distance learning facilities.. Furthermore, mobile learning is equiped with some amazing features that can not be found on other equipments. These features include the ability to take and share images in real time, maps and GPS. Vasiliaou \& Economides, 2011 conclude that mobile learning has served impressive educational and learning facilities by integration with wireless networks, mobile devices and other network technologies.

Software on a large scale is generally built in a distributed way and consists of various media connected in one network. In this context, microservice is a new software development pattern where the overall software functions are provided by smaller software components. These components use and provide software services and are developed by the team separately. Unlike traditional software development where the development team and operational teams are separate, in microservice each team provides all development and operational requirements for services or services built (DevOPs).

The picture below shows an example of a microservice consisting of five services that work together to provide applications for external users.

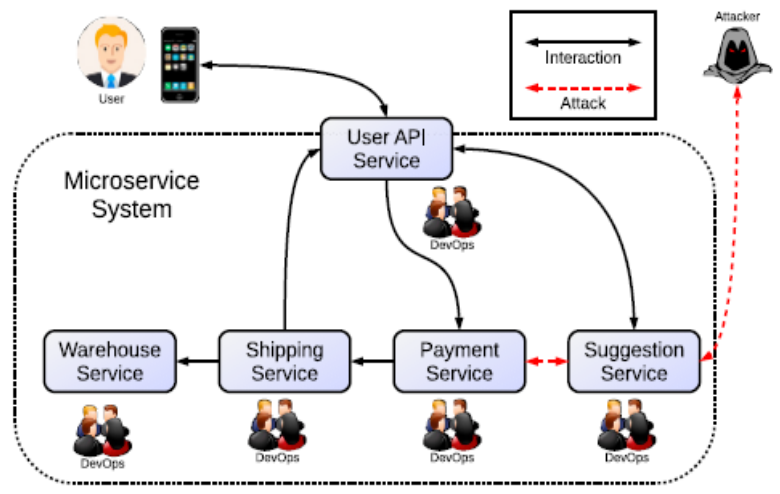

Figure 1: Microservice System 
Users run client applications both mobile applications and web-based applications that access the external User API provided by the system. The service API is indeed an internall service that provides the requested function (warehause service, shipping serice, payment service, suggestion service). Each of these services is maintained by the DevOps team who develop, deploy and maintain the system.

As noted above, the development of software using microservice technology has many advantages compared to conventional technology. Lack of understanding and applied examples of microservice technology is one of the causes of the lack of software developed using this technology. This research aims to implement microservice technology in the development of mobile learning (MLearning). Application of microservice will break applications into entities that stand alone and are isolated from other entities. Thus failure in one entity will not affect the overall application

\section{RESEARCH METHODOLOGY}

The system development strategy utilized in the improvement of this application is Rational Unified Process (RUP). This strategy is utilized on the grounds that the time required in the advancement of this application is generally short and furthermore this application will encounter upgrades amid the improvement procedure.

Rational Unified Process (RUP) software development process that is most broadly utilized today by groups engaged with programming advancement (system analyst, project manager) (Qiali Chen, 2015).

RUP is a software engineering process with great definition and great organizing. RUP gives a decent meaning of structure for programming venture life stream. RUP has four phases or stages that should be possible iteratively. In this strategy there are four phases of programming improvement, in particular:

1. Inception; it is the phase of displaying the business procedure and characterizing the requirement for the framework to be made

2. Elaboration; more spotlight on arranging the framework design. This stage can likewise be made to decide if the coveted framework engineering can be made or not. This stage additionally underlines the examination of framework outline and framework usage and the normal outcomes from this stage are satisfy the turning point engineering lifecycle
3. Construction;this stage is more centered around creating segments or framework highlights.

4. Transition; this stage more on the sending or establishment of the framework with the goal that it tends to be comprehended by the client. Activities at this stage incorporate client preparing, support and framework testing whether they meet client desires.

\section{RESULTS AND DISCUSSION}

\subsection{System Modelling}

The building system can be seen in the following UML diagram (figure 2).

\subsection{System Architecture}

The system architecture that is built refers to the functional requirements obtained from interviews with prospective users and utilizes references from literature studies. Functional requirements are arranged in table form (table 1) and consist of actor requirements and functional requirements. Actors are users who will use applications, namely administrators, teachers and students ).

\section{Table 1. Functional Requirement}

\begin{tabular}{|c|c|c|}
\hline ID & Aktor & Functional Requirement \\
\hline 001 & \multirow{8}{*}{ Teacher } & Make question \\
\hline 002 & & Edit \& update question \\
\hline 003 & & Enter mark \\
\hline 004 & & Edit and delete mark \\
\hline 005 & & Make answer \\
\hline 006 & & Edit and delete answer \\
\hline 007 & & Input learning material \\
\hline 008 & & $\begin{array}{l}\text { Edit and delete learning } \\
\text { material }\end{array}$ \\
\hline 009 & \multirow{6}{*}{ Admin } & Input SMK data \\
\hline 0010 & & Edit and delete SMK data \\
\hline 0011 & & Enter lesson data \\
\hline 0012 & & Edit and delete lesson data \\
\hline 0013 & & Enter user \\
\hline 0014 & & Edit and delete user \\
\hline 0015 & \multirow{2}{*}{ Student } & Asses question \\
\hline 0016 & & Asses mark \\
\hline
\end{tabular}

The architecture of the microsystem service that is built is as in Figure 3. For the implementation of the microservice architecture using the lumen framework. Lumen is part of the laravel framework that is used to develop microsystem. 


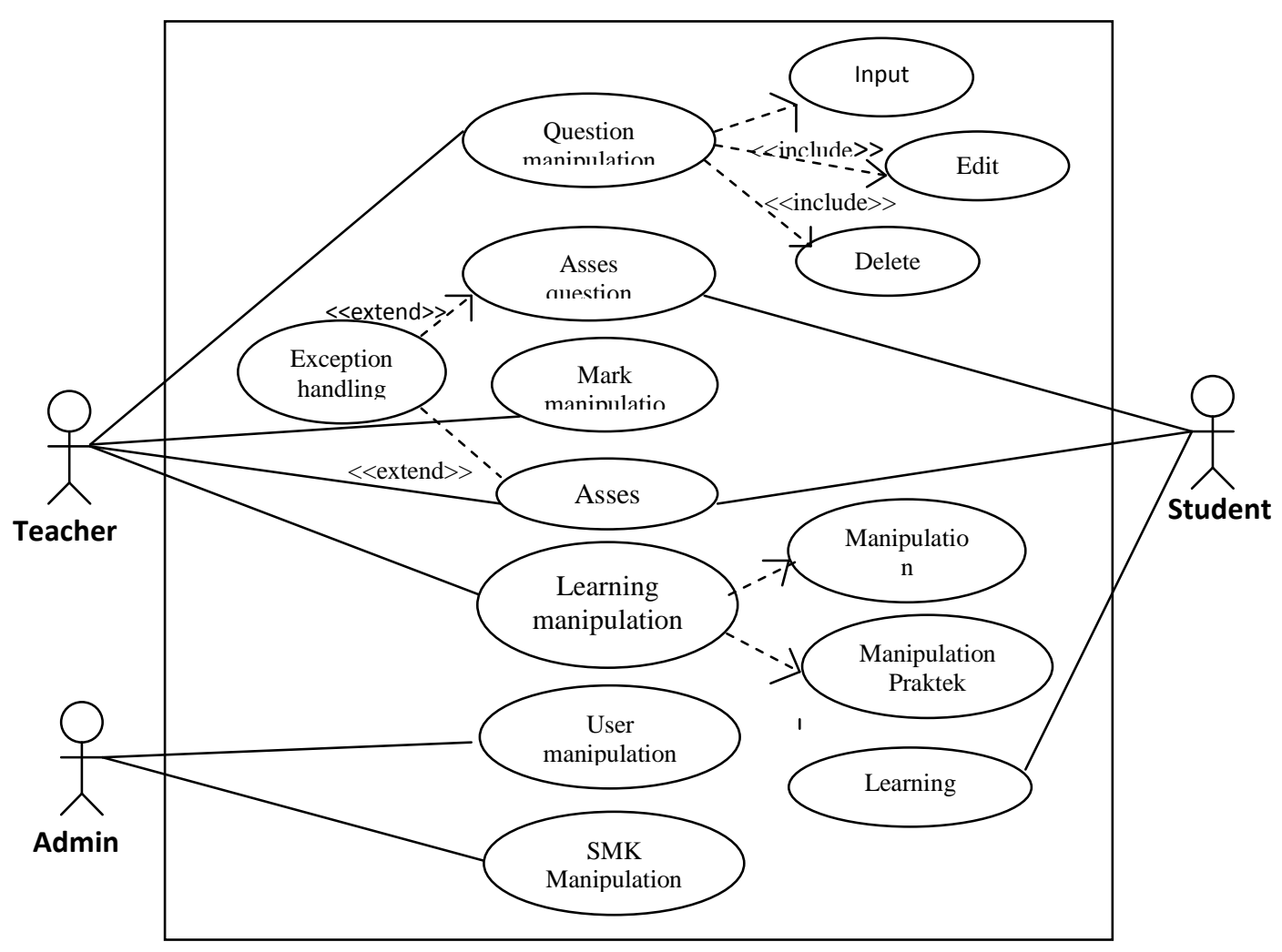

Figure 2: System Modelling

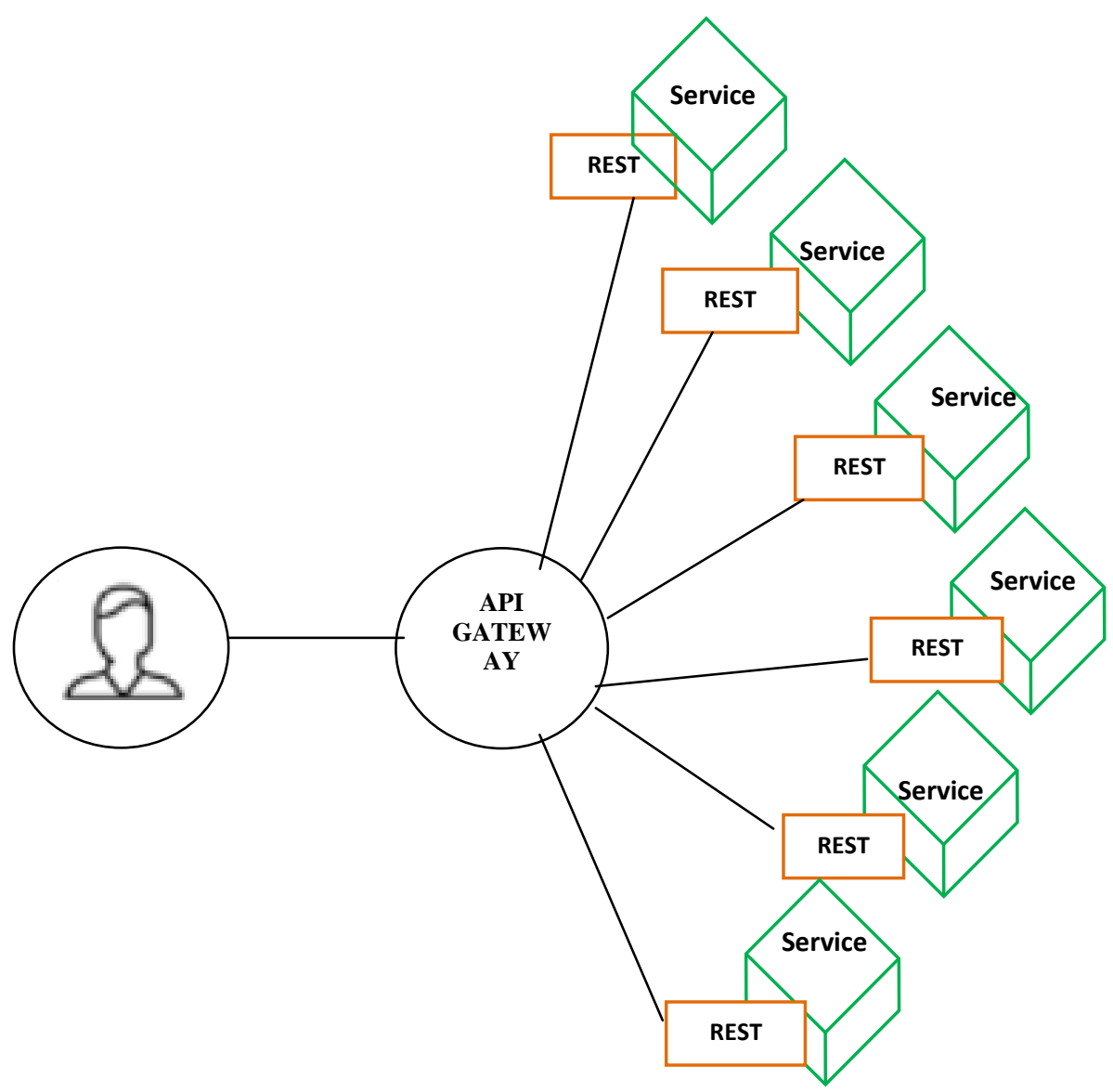

Figure 3: System Architecture 
As shown in the picture above, all requests from users will go through the Gateway API which will then direct this request to a particular service. In addition, the Gateway API has role for the protocol translation and provides the custom API that users need. The gateway API provides an example endpoint (/ question? ProblemID = 101) so that users can access the question with ID number 101. Implementation of the Gateway API and some of the above microsystems can be seen in the following figure

\begin{tabular}{|l|}
\hline Silakan Sign In \\
\hline nip or nis \\
\hline Password \\
Instansi \\
\hline SMK 1 Manado \\
\hline SMK 1 Manado \\
SMK 2 Manado \\
SMK 3 Manado \\
SMK 4 Manado \\
SMK 5 Manado \\
SMK 6 Manado \\
\hline
\end{tabular}

Figure 4: API Gateway

\subsection{System Testing}

System testing in the form of functional testing is carried out to analyze the built-in microservice system. Testing functionality is one of the black box testing that is done to ensure that the system functions as it is modeled / expected. The results of testing functionality can be seen in the table below:

Table 2. Testing Functionality

\begin{tabular}{|c|c|c|c|}
\hline No & Testing & Test Case & $\begin{array}{c}\text { Expected } \\
\text { Result }\end{array}$ \\
\hline 1 & $\begin{array}{l}\text { API Gateway } \\
\text { Functionality }\end{array}$ & $\begin{array}{l}\text { 1. User enters the } \\
\text { URL according to } \\
\text { the desired REST } \\
\text { API } \\
\text { 2. User access the } \\
\text { opened service }\end{array}$ & $\begin{array}{l}\text { 1. User can } \\
\text { access the } \\
\text { desired } \\
\text { service } \\
\text { 2. User can use } \\
\text { service } \\
\text { fiture }\end{array}$ \\
\hline 2 & $\begin{array}{l}\text { Mark } \\
\text { microservice } \\
\text { functionality }\end{array}$ & $\begin{array}{l}\text { 1. User opens form to } \\
\text { input, edit and } \\
\text { update mark based } \\
\text { on certain } \\
\text { parameter } \\
\text { 2. User click submit } \\
\text { button }\end{array}$ & $\begin{array}{l}\text { 1. } \begin{array}{l}\text { Mark can be } \\
\text { input, edit } \\
\text { and delete } \\
\text { based on } \\
\text { certain } \\
\text { parameter }\end{array} \\
\text { 2. Data is valid, } \\
\text { data can be } \\
\text { stored in } \\
\text { database }\end{array}$ \\
\hline 3 & $\begin{array}{l}\text { Question } \\
\text { microservice } \\
\text { functionality }\end{array}$ & $\begin{array}{l}\text { 1. User opens question } \\
\text { form to input, edit } \\
\text { and delete the } \\
\text { question }\end{array}$ & $\begin{array}{l}\text { 1. Question } \\
\text { form is } \\
\text { opened and } \\
\text { question can }\end{array}$ \\
\hline
\end{tabular}

\begin{tabular}{|c|c|c|c|}
\hline No & Testing & Test Case & $\begin{array}{l}\text { Expected } \\
\text { Result }\end{array}$ \\
\hline & & $\begin{array}{l}\text { 2. User click submit } \\
\text { button }\end{array}$ & $\begin{array}{l}\text { be accessed } \\
\text { 2. Validation is } \\
\text { OK and } \\
\text { question can } \\
\text { accessed } \\
\text { from } \\
\text { database }\end{array}$ \\
\hline 4 & $\begin{array}{l}\text { Learning } \\
\text { material } \\
\text { microservice } \\
\text { functionality }\end{array}$ & $\begin{array}{ll}\text { 1. } & \begin{array}{l}\text { User opens } \\
\text { learning form and } \\
\text { input learning } \\
\text { material }\end{array} \\
\text { 2. User chooses } \\
\text { submit button }\end{array}$ & $\begin{array}{l}\text { 1. Learning } \\
\text { function can } \\
\text { be used } \\
\text { 2. Learning } \\
\text { material is } \\
\text { stored into } \\
\text { database }\end{array}$ \\
\hline 5 & $\begin{array}{l}\text { User } \\
\text { microservice } \\
\text { functionality }\end{array}$ & 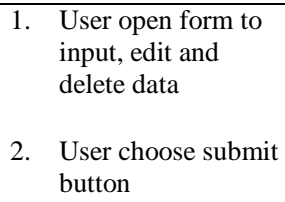 & $\begin{array}{l}\text { 1. User can use } \\
\text { the form } \\
\text { 2. User data can } \\
\text { be stored into } \\
\text { database }\end{array}$ \\
\hline
\end{tabular}

\section{CONCLUSION}

The microservice architecture breaks applications into independent entities that are called through the Gateway API. The mobile learning application that is built has six micservices that can be developed as needed by adding certain services to the existing system. The effective lumen framework for building microservice and supporting the development of RESTFUL API applications

\section{REFERENCES}

[1] Cavus,N., \& Ibrahim,D. (2009). M-Learning: An experiment in using SMS to support learning new English words. British Journal of Educational Technology, 40(1),78-91.

[2] D.V. Sanchez, E.H.Rubio, E.F.Ruiz and Viveros, "Student Role Functionalities Towards Learning Management Systems as Open Platforms Through Mobile Devices", IEEE 201 S. M. Metev and V. P. Veiko, Laser Assisted Microtechnology, 2nd ed., R. M. Osgood, Jr., Ed. Berlin, Germany: Springer-Verlag, 1998.

[3] L.Bass, P.Clements, Software Architecture in Practice, 3rd ed, Boston, MA : Addison-Wesley professional, 2012 , ch. 13

[4] N.Pachler, B.Bachmair, J.Cook and G.Kress, Mobile Learning:Structures, Agency, Practices, 1st ed,New York,NY:Springer,2010,ch. 1,pp. 3-10

[5] N.Serrano, J.Hernantes, and G.Gallado, "Mobile Web Apps", IEEE Software 2013

[6] Qiaoli Chen,Department Of engineering working software teaching and research Shaanxi Institute of technology Xi'an China, "Compare and study about owing to the three kinds important softwares develop process ", international Conference on Education Technology and Economic Management (ICETEM), 2015. 
International Journal of Computer Applications (0975 - 8887)

Volume 182 - No. 23, October 2018

[7] Shen,R., Wang,M. (2008). Increasing interactivity in blended classrooms through a cutting-edge mobile learning system. British Journal of Educational Technology, 39(6), 1073-1086
[8] Vasiliou, A., \& Economides, A.A (2011). Mobile collaborative learning using multicast MANETs. International Journal of Mobile Communications, 5(4), 423-444. 